\title{
DIPHTHERIA TOXOID IN THE TREATMENT OF LEPROSY
}

\author{
CLINICAL AND IMMUNOLOGICAL INVESTIGATIONS
}

A. R. IDavison and E. Grasset

In the Thai Science Bulletin, April I940, Collier' reported on the use of diphtheria toxoid in the treatment of leprosy and this has been followed by a second report in the International Journal of Leprosy January-March I94 $\mathrm{I}^{2}$. His results were very encouraging and in an effort to duplicate them we selected roo cases in July I940 and placed them under observation while undergoing treatment by diphtheria formoltoxoid.

The investigation was approached from (I) the Clinical and (2) the Immunological aspects.

I. Clinical: Forty cases-European and Bantu, were set aside for special study. They comprised a selection of every type and stage of the disease. Sixty cases, mostly Europeans, of the L2 and L3 type completed the series. A monthly record was kept of the weight, bacilliary condition and clinical changes of all cases. The special study group were Schick tested and a monthly record was made of their sedimentation index. They were further divided into four groups of which three received accessory treatment.

2. Immunological: A series of special study cases were Schick tested before treatment. Sixteen representative cases had a titration of diphtheria antitoxin done before and after treatment with a view to the possible correlation between the clinical results and the immunological findings.

\section{Scheme of Immunization and Nature of the Reactions Following Diphtheria Toxoid InjeCtions.}

(I) The diphtheria formoltoxoid used for immunization was prepared in the Serum Department of the South African Institute for Medical Research and was taken from the stocks issued to the public for anti-diphtheritic immunization. It originated from several batches, all prepared from the P.W.No.8 B. Diphtheria strain.

The immunizing properties of the product are tested in accordance with the Union's Therapeutic Substances Regulations. 
(II) Dosaye: The injections were given subcutaneously every fortnight. The dosage was commenced at $\frac{1}{2} \mathrm{cc}$. then I cc. then $I_{\frac{1}{2}}$ cc. followed by 2 cc's. As at this stage there was no sign of any clinical or bacteriological effect the dosage was raised by I cc. at each subsequent injection until a maximum of Io cc's was reached.

(III) Reactions following Diphtheria Toxoid: The local reactions were slight. In most cases there was slight tenderness at the site of the injection for 48 hours. Others showed a zone of erythema around the site-this also faded rapidly. The reactions were only slightly more severe with the larger than with the smaller doses.

General reactions: Following the injection a slight elevation of temperature occurred and complaints of insomnia with pains in the head and shoulders were sometimes received. These complaints increased as the dosage increased above $5 \mathrm{cc}$ 's. One case only, No. 54I, had severe reactions with each injection. The erythema here sometimes encircled the arm and extended from the shoulder to the elbow. The final injection of Io cc's. was followed by the reactionary phase with an acute outcrop of nodules-located almost exclusively to the sites where she had previously received intradermal ethyl esters of hydnocarpus.

(IV) Grouping: As we have been investigating group antigen therapy we took the opportunity to try the effect of combined therapy and the cases were, therefore, divided into 4 groups.

Group 1. Diphtheria toxoid alone.

, II. Diphtheria toxoid plus an emulsion of the whole diphtheria bacillus ( $\mathrm{I}, 000$ millias p.c.c.) the latter given bi-weekly in I-Io cc. doses.

, III. Diphtheria toxoid plus T.B. Endotoxoid, given as above.

," IV. Diphtheria toxoid plus a killed emulsion of a T.B. culture which had lost its acid-fast properties (hereafter called N.A.C.) given as above.

\section{TABLE I.}

Tables of Clinical Findings: The following tables show the type of the disease ( $\mathrm{N}=$ neural, $\mathrm{L}=$ lepromatous), the registered number of the patient and the clinical and bacilliary condition before and after the course of treatment. 
(inoupl.

I) PHTHERIA F(ORM(ITIN(II).

IIII), $19+(1)$.

I.3. 475. New nolules on legs

I.3. 470 . Flat infiltration lace

I.3. 530. Slight early infiltration

I3. 541. Slight early infiltration

1.2. 5+3. Slight early infiltration

I.3. 5rg. Alsorbing infiltration face
IIInse.

L.B.
Acute reactionary 1..B.
phase

L.B. + New infiltration 1.13. + buttocks

I..B. + Infiltation worse I..B. +

I..13. + Infiltration worse 1..13. t Reactionary phase

I.13. + Infiltration worse L.13. + I.B. + Face-no change. I.B. + Erythematous

Total 7 noclules limbs

Vo Change

I.1. 500. Diffuse infiltration face I..B. and trunk

I.r. 507. Erythematous infiltra- L.B. + tion eyebrows

L.3. 532. Diffuse infiltration face

1.3. 539. Slight infiltration trunk

I.3. $5 f^{(0)}$ Infiltration lace. Erythema Norlosum leproticum

I.3. 551. Firm infiltration

I.1. 530. Scarlet plaques

1.3. 520. Infiltration face, back and arms

I.3. 513. Infiltration face. Plaques body

I.3. 480 . Subsiding plaques

I.3. 483. Erythematous infiltration

I. B. +

L.B. +

L.B. +

No ('hatnge

I. I3. +

,

I. 13. +

,

I. I3. +

I..13. +

I. I3.

I..B. +

L.B. +

L.B. +

I.B. +

L.B. +

,

1..13. +

,

I..B. +

,

I..B. +

,

I. B. +

L.B. +

,

I..13. +

,

I..I3. + 1.3. 404. Erythematous intiltra-

L.B. +

Nr. 4.54. No lesions but nasal smear

I..B. + Nasal smear

I. B. +

"

1..13. +

L.B. $+\mathrm{No}$ Change

I..13. + tion

I.3. 449. Heavy infiltration

L.B. +

L.B. +

L.B. +

Diffuse infiltration

L.B. +

Erythematous plaques

1.3. 344

1.3. 314 .

Infiltration face

L.B. +

L.B. -

N2. 549. Erythematous macules

I.3. 7788. Heavy infiltration

L.B. +

N2. 7817. Raised margins macules.

L.B. L3. 7232. Erythematous infiltra-
tion, no rugae

I.3. 6750 . Face infiltration

L.B. + No Chavige

L.B. +

Total 24 .

",
",
",
",
üles Hatter
ut new outcrop
of macules

I..B. +

I.B. +

I.. B. +

I.B. +

I.B. +

I..B. -

L.B. ++

L.B. -

I..B. + scanty

I..B. ++

Slight Improvement.

I.3. 499. Multiple erythematous L.B.+ Lesions Hatter lepromatous lesions and browner

L,2. 529. Trace erythematous in- L.B. + Jess erythema filtration face

$N_{\text {I. }} 5+8$. Raised erythema

L.B. - Macules red lut

I.. B. + macules flat.

1.2. $5 f^{\text {(). Subcutancous nolules }}$

L.13. + Nolules absorluel

I..B. but skin shows 

L2. 53.5. Infiltration ear lolues L..B. + Infiltration ab- I..B. + and buttocks sorbed buttocks
I.3. 527. Trace infiltration face L..B. + Infiltration less I..B. +
I.3. 524. Slight infiltration I..B.+ Infiltration less I.B. +
1.2. 515. Trace Hat erythematous I..B. + Erythema farling L.B. - lepromata on arm
I.3. 492. Slight rugae forehead L.B3. + Sikin more pliahle J..B. +
Ni. 47.3. Pink raised macule's L.B. - Less raised L.B. -
L.3. 479. (ieneralised infiltration I.B. + More pliahlo e L.B. +
N2. 606.5. Erythematous macules I..B. - Flatter and less 5..B.- raised erythematous
N2. 77.39. Spongy tuberculoid I.B. - Less raised L.B. - minor macules
N2. 7713. Spongy tuberculoid L.B. - I,ess raised but I.B. + minor macules
Total 14.

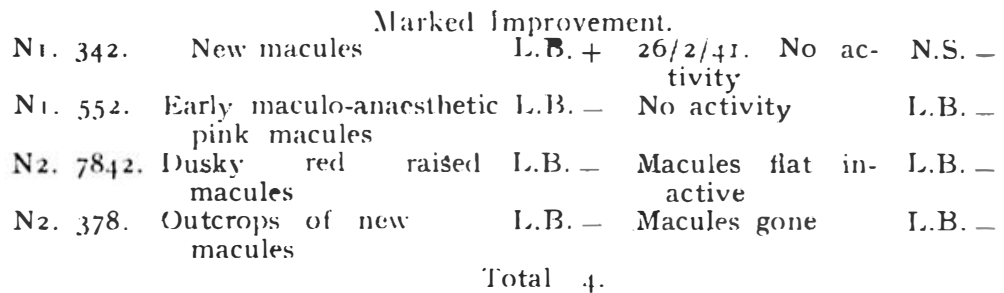

Conclusion:

Only four cases out of 48 showed marked improvement. These were all neural cases who would have responded equally well to intradermal ethyl esters of hydnocarpus.

\section{Grour 11.}

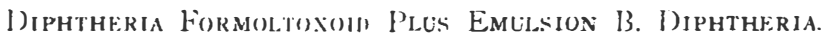
Iuly, 1940. February', 1941.

II urse.

N2. 407. New maculae back and L.B. - New maculae face, I.B. + abdomen

N3. 7851. Trace erythema of some L.B. - Infiltration fore- L.B. + macules others healed

I.3. 6663. Small 6d. sized plaques

arms

Total 3.

Multiple new $\quad$ L.B. + plaques

No Change.

N . 544. Slight erythema maculae L.B. - No Change L.B. -

Lr. 547. Slight infiltration face L.B. + , $\quad$ L.B. +

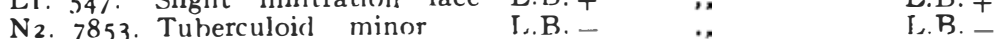

maculae
N2. 78.5.5. Flat pale macules $\quad$ L.B. , ,

Total 4.

Slight Improvement.

I. . 538. Erythematous macules L.B. + Macules fading. L.B. + with one plaque

Plaque persists

N2. 7738. Slightly erythematous L.B. - Less raised and raised margins red

N2. 7838. Raised brown macules L.B. - I.ess raised more

I.1. $78+7$. Raised erythematous L.B. + Plaques flatter I.IB. plaques lotal 4. 


\section{Conclusion :}

The addition of emulsion of B.Diphtheria did not favourably influence the effect of diphtheria toxoid.

Cikoup 111.

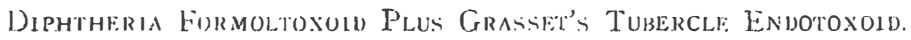

$.111 y, 19+1)$.

L3. 7438. Small plaçues

$\mathrm{N}_{1}$. 7608 . Filat pale macules

licbruary, $19+1$.

IIorse. L.13. + Intiltration worse L.B. + L..13. - Ratised red new I.13. -

Total 2.

No (hange.

L.3. 381 . Diffuse infiltration trunk I..B. +

L.3. 7601. Diffuse infiltration face L...3. +

Slight improvement.

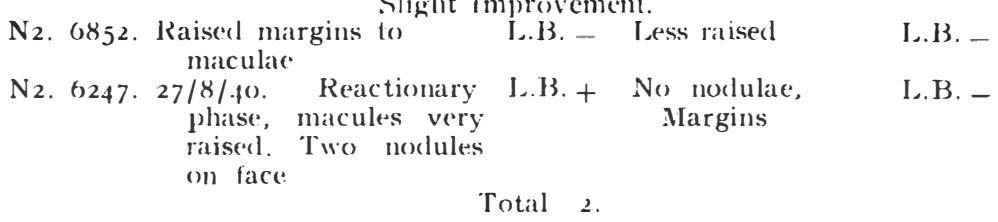

Narked Improvement.

N2. 7872 . Very raised black mar- L.B. - No activity in L.B. gins to maculae

Total 1.

resiclual maculae

L.B. +

L.B. +

Conclusion:

Only one case showed marked improvement under diphtheria formoltoxoid plus Grasset's tubercle endotoxoid. The small number of cases does not permit a true appreciation of the value of this combined treatment.

\section{GRote IV.}

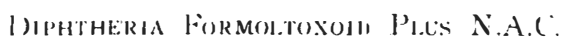

$$
\text { Iuly, } 19.41) \text {. }
$$

$$
\text { IVorse. }
$$

licbruary', 19.11.

Nil.

\section{No Cliange.}

L.3. 7 to.5. Early infiltration.
C.hronic reactionary
phase

N2. 6007. Raised dusky spread- L.B.- , , L.B. ing macules

I.3. $76+5$. slight ervthematous in- L.B. filtration face

N 2. 7305 . Ratised erythematous pea-sized macules

L.B. -

L. B. ++

,

L.B. -

Total 4 .

Slight Improvement.

N3. 7667. (irey granular macules L.B. + Now macules are L.B. Total 1. flat and pale

Marked Improvement.

Nil. 
Conclusion :

The combined treatment by diphtheria formoltoxoid plus N.A.C. is not of obvious value, but the number of cases is small.

TABLLI: $1 \mathrm{I}$.

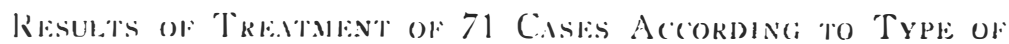

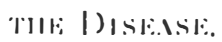

\begin{tabular}{|c|c|c|}
\hline & & $\mathrm{N}$ \\
\hline (AStS & & \\
\hline \multicolumn{3}{|l|}{ 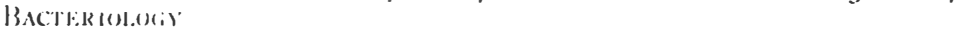 } \\
\hline Negative thr & sughout. & \\
\hline Positive to & Negativ & \\
\hline Negative to & Positiv & \\
\hline Persistently & Postive. & \\
\hline \multirow{2}{*}{\multicolumn{3}{|c|}{$\begin{array}{l}\text { SKIN LASIONS } \\
\text { Improved }\end{array}$}} \\
\hline & & \\
\hline No change. & ... & \\
\hline IVorse ... & $\ldots$ & \\
\hline
\end{tabular}

Clinical Investigation. Treatment was naturally voluntary and the first significant fact which emerges is that only $7 \mathrm{I}$ patients completed the seven months course. It is no doubt the common experience that leprosy patients will persist with any treatment, however panful, where they can observe any improvement. In the 25 cases who showed improvement in the final assessment it was noted that improvement had occurred in the early months, but the changes were slight and were probably not obvious except to a leprologist. Changes recorded were " maculæ flatter and paler," " erythema less in infiltrated areas," " maculæ healing in centre," " maculx not so spongy" and " infiltrated skin more pliable." Such changes of course occur as natural fluctuations of the disease and occur whether a patient is under treatment or not. But it is encouraging that these changes persisted. The only clinical changes of real significance are the five cases recorded as " Marked Improvement."

Weight-no changes were observed which did not conform to ordinary seasonal changes, i.e., during the winter football season our patients show, on an average, a lower weight.

Sedimentation. Index-our sedimentation index is read at the end of one hour - the blood having been mixed with potassium oxalate. We do not regard the index as showing any direct relation to the leprotic condition but it does reflect intercurrent infections, or causes of debilitation, e.g., septic feet or fingers. The average sedimentation index of these cases under treatment showed no alteration one way or the other.

Bacilliary condition-not only the presence or absence of bacilli was noted but the degree of fragmentation or clubbing of the 
bacilli. During the period of observation we were cheered to notc fragmentation occurring in many cases but were again disappointed to find these cases at later dates showing normal bacill. Only fiv' $\epsilon^{\prime}$ of the cases previously showing bacilli are now negative, but on the other hand six cases previously negative are now showing bacilli.

\section{IMMLNULUGICAL INIRSTIGATIONS}

As stated above, a series of sixteen patients was selected for these investigations. Five were European, all adult females, and eleven were natives, of whom nine were males, including eight adults and a child of nine years and two adult females.

These patients were Schick tested and the diphtheria antitoxin content of their blood was titrated before and after immunization.

\section{Schick Test.}

The Schick test material used was prepared at the South African Institute for Medical Research. The toxin was a matured diphtheria toxin prepared in 1937 from the P.W. No. 8 . B.diphtheria strain. Glenny's modified buffer solution was used for the dilutions. This Schick test material is controlled in accordance with the Union Therapeutic Substances Regulations.

0.2 c.c. of the Schick test material was injected intradermally in the right forearm in a non-affected area; 0.2 c.c. of the control heated Schick solution was similiarly injected in the left forearm. The reactions were read after $24,48,62$ and 86 hours.

\section{Results of Schick tests before Immunization.}

The results are given in column 5 of Table III. They show that three out of five of the European patients exhibited a positive Schick reaction, one after 24 and the second after 48 hours; the third showed a less typical, delayed reaction, which appeared only on the third day. All the natives proved to be non-reactors, i.e.. Schick negatives. This last finding agrees with the observations referred to in previous immunological studies on the antidiphtheritic immunity among Bantus (E. Grasset and others, I933) ${ }^{3}$, that a considerably higher rate of Schick non-reactors is shown among South African Natives than among Europeans.

\section{Antitoxin Titration.}

The antitoxin titration of the serum of these patients befori immunization was carried out by means of the Römer method modified by $Z$ ingher ${ }^{4}$, by intradermal injections of toxin-antitoxin mixtures in guineapigs, which allows the determination of minute amounts of antitoxin. The titrations were done within wide limits, from I/500 antitoxin unit to I/IO0 u., I/50 u., I/25 u., 
I/10 U., and I/2 antitoxin unit per cc. These results are to be found in column 5 of Table III.

Titration of diphtheria antitoxin was again carried out on the serum of the same patients after a course of 6 months of diphtliciru toxoid immuni ation. Blood was taken from thirteen patients on the IIth February, I94I, i.e., 3 weeks after the last toxoid injection, but from three patients (Nos. 407, 499 and 7847) samples of blood could only be taken on the 7 th May, i.e., about 4 months after immunization.

Preliminary titrations covering a wide range indicated a considerable increase of the antitoxic contents of most of the sera. Further titrations by means of the Ehrlich method, using one guineapig per mixture, were carried out to end titre for each serum from a minimum of $\mathrm{I} / 2$ unit to a maximum of 50 units, according to the following increasing dosage: 0.5 u., I u., 5 u., IO u., 20 l.., $30 \mathrm{u}$., and 50 antitoxic units per cc. of serum.

The results of these titrations are indicated in column 6 of Table III. In only one case was the antitoxic titre found to be less than $I / 2$ u. lt corresponds to one of the two Schick positive European patients, whose titre before immunization was below I/500 u. per cc. By contrast the titre of the second case-also Schick positive originally, and less than I/500 per cc.--reached Io $<20$ units per cc. after immunization.

Classification of the antitoxic contents of the series of sera into groups corresponding respectively to $<\mathrm{I}$ u.; I to $5 \mathrm{u}$.; 5 to IO $\mathrm{u}$.; Io to $20 \mathrm{u}$.; 20 to $30 \mathrm{u}$.; and > $30 \mathrm{u}$., is shown in Table IV.

Table III-see next page

TABLE IV.
$\begin{aligned} & \text { Antitoxin titre } \\ & \text { in units } \\ & \text { per c.c. }\end{aligned}$
$\begin{aligned} & \text { Number } \\ & \text { of }\end{aligned}$
$\begin{aligned} & \text { Sera } \\ & \text { Sera }\end{aligned}$

It can be seen that the group containing the highest number of cases is that corresponding to I0-20 units, represented by 7 cases, i.e., $43.75^{\circ}$ per cent of the total of the cases. Although the number of cases included in these titrations is small, and has no statistical value, some interesting observations can nevertheless be drawn from these investigations.

On the whole the immunity response to diphtheria toxoid is 
TABLE III.

Results of Titration of Diphtheria Antitoxin in Leper Cases Immunized with Diphtheria formol Toxoid (Anatoxin).

\begin{tabular}{|c|c|c|c|c|c|c|c|c|c|c|c|}
\hline \multirow{2}{*}{$\begin{array}{l}\text { Patient's } \\
\text { Number. }\end{array}$} & \multirow{2}{*}{ Race. } & \multirow{2}{*}{ Age. } & \multirow{2}{*}{$\begin{array}{l}\text { Schick } \\
\text { Test. }\end{array}$} & \multicolumn{6}{|c|}{ Titration in units per c.c. of serum. } & \multirow{2}{*}{$\begin{array}{c}\text { Amount of } \\
\text { Diphtheria } \\
\text { Toxoid Injected } \\
\text { in c.c. }\end{array}$} & \multirow{2}{*}{ Clinical Results. } \\
\hline & & & & Before & $\mathrm{am}$ & nization. & After Ir & nur & ization. & & \\
\hline $\begin{array}{r}547 \\
538 \\
407 \\
499 \\
378\end{array}$ & 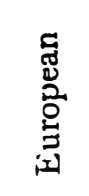 & $\begin{array}{ll}23 & \text { yrs. } \\
36 & \text { yrs. } \\
25 & \text { vrs. } \\
32 & \text { yrs. } \\
25 & \text { yrs. }\end{array}$ & $\begin{array}{l}- \\
+ \\
\pm \\
+ \\
+\end{array}$ & $\begin{array}{l}\text { I/IO } \\
\text { I/50 } \\
\text { I/IO }\end{array}$ & $\begin{array}{l}< \\
< \\
< \\
< \\
<\end{array}$ & $\begin{array}{l}I / 2 \\
I / 500 \\
I / 25 \\
I / 2 \\
I / 500\end{array}$ & $\begin{array}{r}20 \\
\text { I } / 2 \\
\text { I0 } \\
\text { IO }\end{array}$ & $\begin{array}{l}< \\
< \\
< \\
< \\
<\end{array}$ & $\begin{array}{l}30 \\
1 / 2 \\
I \\
20 \\
20\end{array}$ & $\begin{array}{l}65 \\
17 \cdot 5 \\
37 \cdot 5 \\
39 \\
50\end{array}$ & $\begin{array}{l}\text { No change } \\
\text { Slight improvement } \\
\text { Worse } \\
\text { Slight improvement } \\
\text { Worse }\end{array}$ \\
\hline $\begin{array}{l}6965 \\
7838 \\
7739 \\
6663 \\
7855 \\
7851 \\
7847 \\
6750 \\
7817 \\
7788 \\
7842\end{array}$ & 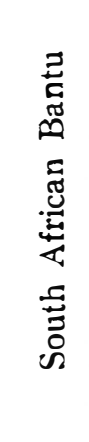 & $\begin{aligned} 43 & \text { yrs. } \\
\text { I9 } & \text { yrs. } \\
9 & \text { yrs. } \\
6 \text { I } & \text { yrs. } \\
4 \mathrm{I} & \text { yrs. } \\
25 & \text { yrs. } \\
66 & \text { yrs. } \\
26 & \text { yrs. } \\
46 & \text { yrs. } \\
28 & \text { yrs. } \\
20 & \text { yrs. }\end{aligned}$ & $\begin{array}{l}- \\
- \\
- \\
- \\
- \\
- \\
- \\
- \\
-\end{array}$ & $\begin{array}{l}\text { I/2 } \\
\text { I/50 } \\
\text { I/25 } \\
\text { I/25 } \\
\text { I/2 } \\
\text { I/IO } \\
\text { I/IOO } \\
\text { I/IOO } \\
\text { I/IO } \\
\text { I/IOO } \\
\text { I/IO }\end{array}$ & $\begin{array}{l}> \\
< \\
< \\
< \\
> \\
< \\
< \\
< \\
< \\
< \\
<\end{array}$ & $\begin{array}{l}\mathrm{I} / 25 \\
\mathrm{I} / \mathrm{IO} \\
\mathrm{I} / \mathrm{IO} \\
\mathrm{I} / 2 \\
\mathrm{I} / 50 \\
\mathrm{I} / 50 \\
\mathrm{I} / 2 \\
\mathrm{I} / 50 \\
\mathrm{I} / 2\end{array}$ & $\begin{array}{r}10 \\
10 \\
1 \\
40 \\
1 \\
20 \\
1 \\
10 \\
10 \\
10 \\
5\end{array}$ & $\begin{array}{l}< \\
< \\
< \\
< \\
< \\
< \\
< \\
< \\
< \\
< \\
<\end{array}$ & $\begin{array}{r}20 \\
20 \\
5 \\
50 \\
5 \\
30 \\
5 \\
20 \\
20 \\
20 \\
10\end{array}$ & $\begin{array}{l}66 \\
78 \\
42 \\
67 \cdot 5 \\
72 \\
75 \\
67 \\
37 \\
55 \\
67 \\
56\end{array}$ & $\begin{array}{l}\text { Slight improvement } \\
\text { Slight improvement } \\
\text { Slight improvement } \\
\text { Worse } \\
\text { No change } \\
\text { Worse } \\
\text { Slight improvement } \\
\text { No change } \\
\text { No change } \\
\text { No change } \\
\text { Marked improve- } \\
\text { ment }\end{array}$ \\
\hline
\end{tabular}


satisfactory. Individual differences like those recorded are similarly observed among series of normal immunized subjects. They are also liable to include exceptional instances of individuals who respond poorly to active immunization.

The two instances given by serum No. 538 and No. 407 of our series, with a respective titre of less than $\mathrm{I} / 2$ unit and of $\mathrm{I} / 2$ unit, nevertheless represent an appreciable proportion for a small number of cases; i.e., I2 per cent, a percentage higher than would be normally expected. (No. 538 received only 17.5 cc. of Toxoid.)

Finally, if we attempt to correlate the rate of antitoxin contents of the respective sera with the clinical condition of the patients, as compared with before and after immunization, we come to the conclusion that no relation can be established between the antitoxin titre reached after treatment, and the clinical changes observed in those patients. As indicated in the last column of Table III only one case, No. 7842, of the 16 patients of this series has shown a marked improvement after treatment. His antitoxin titre was determined originally as I/IO $\mathrm{u}$., and reached $5 \mathrm{u}$. after immunization.

On the other hand, the antitoxin titre of the four patients whose condition is indicated as "worse," are to be found from the lowest to the highest titres observed, respectively, I/2 u. for Ser. No. 407, ro u. for Ser. No. 378, $20 \mathrm{u}$. for No. 785I, and $40 \mathrm{u}$. for No. 6663.

With regard more particularly to the two patients originally Schick positive, and with a titre of less than I/500 u. before treatment, one, as mentioned above, gave a very poor immunity response with less than $\mathrm{I} / 2 \mathrm{u}$. after immunization, accompanied nevertheless by a " slight improvement" of his condition. In the second case the antitoxic titre reached ro units after immunization, without however any appreciable clinical change. With regard to the third patient, who showed a delayed Schick reaction with antitoxic contents of $\mathrm{I} / 50 \mathrm{u}$. before immunization, his titre, after toxoid injections, remained low $-\mathrm{I} / 2 \mathrm{u}$. per cc.- -and his condition became worse.

From the therapeutic point of view, Collier.'s suggested line of treatment, based on a suprarenal stimulation, does not appear to have attained the expected results in our series, in spite of repeated and increasing doses of diphtheria toxoid spread over a period of several months.

Regarding the hypothesis of an eventual group neutralisation of the leper toxin by diphtheria antitoxin, the rate of circulating antitoxin after active immunisation, would appear sufficient in the yarger number of cases of our series, to exert such action. 
Out of 72 cases who completed the course of treatment, I2 became worse, 34 showed no appreciable clinical change, 2 I showed a slight improvement, and 5 a marked improvement. The proportion of our cases who appear to haye really benefited by the treatment is only 6.94 per cent, compared with 50 per cent or more as reported for Collier's series.

We are unable to propose any reason for the differences between the clinical findings observed in our series, and the results claimed in a great majority of the cases treated by Dr. Collier using a similar diphtheria toxoid treatment in Thailand.

\section{Discussion :}

Collier's theory that suprarenal inefficiency was a necessary predisposing cause of leprosy seemed strange to us as in reviewing the cases which had passed through our hands, a total of nearly 5,000 , not one case of gross deficiency could be traced, and if every leprosy case had some deficiency it seemed natural to expect that some would have shown extreme degrees of deficiency at least such as would be clinically discernable. In further investigations a hundred cases were selected at random and their blood pressures recorded. These were found to be entirely within the normal range. Eight successive post-mortem of non-treated cases had their suprarenals examined and no anatomical degeneration could be discovered.

During the period of toxoid immunization no evidence of suprarenal deficiency was evoked such as collapse, or a sudden fall in the blood pressure or any undue systematic reaction following the injection even of the larger doses. Only one case, already referred to, showed severe local reactions.

\section{Conclusion:}

According to Collier's suggested line of treatment, roo leper patients were submitted to diphtheria formol toxoid immunization, in increasing doses from $0.5 \mathrm{cc}$. to ro $\mathrm{cc}$. spread over a period of seven months. The results were assessed nine months after beginning the treatment, and were based on clinical changes, weight, bacteriological examinations and sedimentation rate.

Of the 72 cases who completed the treatment, I2 became worse, 34 showed no appreciable change, 2I showed a slight Improvanent and 5 (6.94 per cent) a marked improvement.

A series of 16 patients were Schick tested before immunization and the antitoxin of their blood was titrated before and after treatment. The immunity response was found to be satisfactory in the majority of cases. 62.5 per cent of the patients showed an antitoxin titre of ro units or more per cc. of serum. No relation could 
be established between the antitoxin titre reached after toxoid treatment and the clinical changes observed in these patients.

We cannot suggest any reason for the very limited therapeutic results observed in our series, as compared with those claimed in the majority of cases submitted to a similar treatment by Collier.

\section{Aiknowlidgments:}

We wish to thank Professor A. Sutherland Strachan and Dr. F. W. Simson of the Department of Pathology of the South African Institute for Medical Research, for their much appreciated contribution to these investigations in the examination of postmort'm. specimens, and Mr. A. W. Schaafsma (Senior Technician, Serum Department) for his valuable assistance with titration of the sera. Also we have to thank Dr. Peter Allen, Secretary for Public Health and for the Union of South Africa, for authority to conduct this investigation.

\section{References:}

1. Collier, 1). R. and Mckean, T. H. The use of cliphtheria antitoxin and toxoid in Leprosy $-\Lambda$ preliminary report. Thai Science Bulletin, April, 1940. Vol. II. p.117-12.5.

2. Collier, D. R. The use of Diphtheria Toxoid in the treatment of leprosy. Intcrmational Jourmal of Icprosy r94 I No. I. p.I-Io.

3. Zingher, A. A modification of Roemer's intracutaneous method for the determination of small amounts of diphtheria antitoxin in blood sera. J.Infect.l)is. r9i6, 19, p.5.57-564.

4. Cirasset, E., Perret-(ientil, A., Friedman, J., and Gross, I. Studies on the nature of anti-diphtheritic immunity among South African Bantu by, means of the Schick test and antitoxin titrations. S.Afr.Med.J.. 19) $33,7, p \cdot 779-785$. 